\title{
PERANAN TNI DALAM PEMBERANTASAN TERORISME PERPEKTIF PERTAHANAN KEAMANAN NEGARA
}

\author{
Denny Puspitasari \\ email: denispuspita73@gmail.com \\ Sunny Ummul Firdaus \\ Firdaussunny@yahoo.com \\ Agus Riwanto \\ agusriewanto@yahoo.com \\ Dosen Fakultas Hukum UNS
}

\begin{abstract}
Abstrac
This research aimed to analyze the identification of legislation about terrorism eradication by TNI (Indonesian Army) and to study the legal politics built by government regarding the policy of terrorism eradication by TNI viewed from state defense and security. The method employed in this research was normative one, the method using primary law materials including legislations and secondary law materials or literature including legal principles, legal procedure, vertical and horizontal synchronization (interrelated legislations). This research employed statute approach with comparative analysis on law concepts. The statute approach was carried put by studying regulation or legislation related to legal issues, in this case, the role of TNI in eradicating terrorism in the State Defense and Security perspective to be analyzed. The result of research showed that the identification of legislation about terrorism eradication by TNI (Indonesian Army) still had relevance to the following law: Article 30 of UUD 1945 (1945 Constitution), Republic of Indonesia Police's Law No. 22 of 2002, Law about Terrorism Crime No.15 of 2003, TNI (Indonesian Army) Law No.34 of 2004 and State Defense Law No.3 of 2002. The politics of law built by government should be able to create a responsive law product corresponding to t he ideals of Indonesian law as included in the $4^{\text {th }}$ paragraph of Preamble of 1945 Constitution.
\end{abstract}

Keywords: TNI, politics of law, terrorism, defense and security

\begin{abstract}
Abstrak
Penelitian ini bertujuan untuk menganalisis identifikasi peraturan perundangundangan tentang pemberantasan terorisme oleh TNI,kemudian mengkaji bagaimana politik hukum yangdibangun pemerintah tentang kebijakan pemberantasan terorisme oleh TNI ditinjau dari aspek pertahanan dan keamanan Negara.Metode yang digunakan dalam penelitian ini adalah metode penelitian normatif,yaitu metode yang menggunakan bahan bahan hukum primer seperti peraturan perundang- undangan dan bahan hukum sekunder atau kepustakaan,mencakup asas-asas hukum, sistematik hukum, sinkronisasi vertical
\end{abstract}


dan horizontal(peraturan perundang-undangan yang berkaitan).Penelitian ini menggunakan metode pendekatan perundang-undangan,analisa konsep hukum,perbandingan hukum. Metode pendekatan perundang-undangan dilakukan dengan menelaah regulasi atau perundang-undangan yang berkaitan dengan isu hukum yaitu Peranan TNI dalam pemberantasan Terorisme perspektif Pertahanan Keamanan Negara yang akan di analisis.Hasil penelitian menunjukkan bahwa identifikasi hukum peraturan perundang-undangan tentang pemeberantasan Terorisme oleh TNI yang masih mempunyai relevansi hukum diantaranya adalah UUD 1945 pasal 30.,Undang-undang kepolisian Negara RepubliK Indonesia no 22 Tahun 2002,Undang-undang tentang Tindak Pidana Terorisme No 15 Tahun 2003,Undang-undang TNI no 34 tahun 2004 dan Undang-undang Pertahanan Negara no 3 tahun 2002.serta Politik Hukum yang dibangun Pemerintah harus mampu menciptakan produk hukum yang responsive sesuai dengan cita cita hukum Indonesia sesuai dengan Pembukaan UUD 1945 Alinea 4

Kata Kunci: TNI;politik hukum; terorisme; pertahanan dan keamanan.

\section{A. Pendahuluan}

Undang-undang Dasar 1945 (UUD 1945) adalah konstitusi negara Indonesiayang merupakan hasil kesepakatan seluruh rakyat Indonesia. Keberlakukan UUD 1945 ini berlandaskan pada legitimasi kedaulatan rakyat sehingga UUD 1945 merupakan hukum tertinggi dalam kehidupan berbangsa dan bernegara. Oleh karena itu, hasil-hasil perubahan UUD 1945 akan berimplikasi terhadap seluruh lapangan kehidupan berbangsa dan bernegara. Sampai dengan saat ini, perubahan yang telah dilakukan meliputi banyak materi UUD 1945. Jika naskah asli UUD 1945 berisi 71 butir ketentuan, maka setelah empat kali mengalami perubahan materi muatan UUD 1945 mencakup 199 butir ketentuan.(Jimly Asshiddiqie, , 2003 :1)

Salah satu pasal yang mengalami perubahan adalah pasal 30 UUD 1945. Pasal 30 UUD 1945 memuat tentang pemisahan antara TNI dan POLRI. Kemudian setelah itu, pemisahan tentang kedua institusi tersebut diatur melalui berbagai undang-undang. Saat ini sekiranya berlaku, tiga undangundang dalam pengaturan bidang pertahanan keamanan, yakni UndangUndang No. 2 Tahun 2002 Tentang Kepolisian Negara, Undang-undang No. 3 Tahun 2002 Tentang Pertahanan Negara, dan Undang-undang No. 34 Tahun 2004 tentang Tentara Nasional Indonesia. 
Ketiga Undang-undang tersebut berfungsi mengatur tata laksana tugas pokok dan wewenang TNI dan Polri di bidang pertahanan keamanan negara meskipun memiliki tugas dan peran yang berbeda. Namun, pada prakeknya TNI dan Polri saling melengkapi dan melindungi guna mempertahankan keamanan negara. Sesudah reformasi nasional, diadakan pemisahan yang tegas antara kedudukan dan peran TNI dan Polri, sehingga ABRI ditiadakan. Pemisahan tersebut ditetapkan dengan Tap MPR No. VI/ MPR/ 2000 tentang pemisahan TNI dan POLRI, serta Tap MPR No. VII/ MPR/ 2000 tentang peran TNI dan POLRI. Berdasarkan hal itu, pada tahun 2002 diundangkan UU No. 2 Tahun 2002 tentang Kepolisian Negara Republik Indonesia, serta UU No.3 Tahun 2002 tentang Pertahanan Negara (Lembaran Negara Republik Indonesia Tahun 2002 Nomor 3, Tambahan Lembaran Negara Republik Indonesia Nomor 4169).

Upaya pertahanan negara diperlukan agar Negara Kesatuan Republik Indonesia terjaga dan terlindungi dari ancaman terhadapnya, baik yang berasal dari luar negeri maupun dari dalam negeri. Yang dimaksud ancaman dari dalam negeri tentu tidak berarti ancaman yang sepenuhnya berasal atau dilakukan oleh kekuatan-kekuatan dari dalam negeri saja, karena pemberontakan-pemberontakan bersenjata bisa saja mendapat dukungan dari kekuatan di luar negeri. Dukungan yang diberikan dapat berupa dukungan politik, dukungan dana, bahkan dukungan persenjataan .(http://www.tempointeraktif.com/hg/nasional/2007/06/30/brk,20070630102858,id.html, diakses pada 5 Maret 2017, pukul 11.00)

Menyadari hal ini dan lebih didasarkan pada peraturan yang ada saat ini yaitu Kitab Undang-Undang Hukum Pidana (KUHP) belum mengatur secara khusus serta tidak cukup memadai untuk memberantas Tindak Pidana Terorisme, Pemerintah Indonesia merasa perlu untuk membentuk UndangUndang Pemberantasan Tindak Pidana Terorisme, yaitu dengan menyusun Peraturan Pemerintah Pengganti Undang-Undang (Perpu) nomor 1 tahun 2002, yang pada tanggal 4 April 2003 disahkan menjadi Undang-Undang dengan nomor 15 tahun 2003 tentang Pemberantasan Tindak Pidana 
Terorisme.(http://www.scribd.com/doc/4683235/terorisme-, diakses pada 5 Maret 2017, pukul 11.00WIB.)

Berdasarkan latar belakang maka penulis ingin mengkaji tentang implementasi peran TNI dalam menghadapai terorisme dalam perspektif pertahanan negara.

\section{B. Metode Penelitian}

Jenis penelitian adalah penelitian hukum normatif atau penelitian hukum doctrimal yang penekanannya pada teori teori hukum, bahan-bahan hukum primer dab sekunder. Penelitianini merupakan penelitian yang memberikan penjelasan yang sistematis hubungan antara hubungan serta menjelaskan hambatan-hambatan dan mungkin memprediksi pembangunan masa depan (peter mahmud marzuki, 2011:32) sehubungan dengan jenis penelitian yang digunakan adalah normatif, maka pendekatan penulisan yang digunakan dalam penulisan hukum ini adalah statue approach (pendekatan perundang-undangan dan consectual approach (pendekatan konsentual)

\section{Hasil Penelitian dan Pembahasan}

\section{Teori Tentang Terorisme}

Terorisme adalah serangan-serangan terkoordinasi yang bertujuan membangkitkan perasaan teror terhadap sekelompok masyarakat. Berbeda dengan perang, aksi terorisme tidak tunduk pada tata cara peperangan seperti waktu pelaksanaan yang selalu tiba-tiba dan target korban jiwa yang acak serta seringkali merupakan warga sipil.Menurut $\mathrm{J}$. Bowyer Bell, terorisme adalah sebagai senjata kaum lemah, tapi senjata yang ampuh untuk mempengaruhi pihak lain yang kuat, sedangkan David Fromkin lebih meninjau dari sisi target dan sarana, terorisme adalah sutau upaya mempengaruhi pihak lain dengan mengandalkan perubahan psikologis pihak lain. Terorisme terjebak dalam aksi kekerasan dan sadisme. Keterjebakan itulah menjadikan aksinya menjadi crime secara universal, sehingga tujuamn luhur kemudian menjadi pudar karena kurangnya tranparansi.(http/kompak.com. tangggal 12 Maret 2007.) 
Kegiatan terorisme mempunyai tujuan untuk membuat orang lain merasa ketakutan sehingga dengan demikian dapat menarik perhatian orang, kelompok atau suatu bangsa. Biasanya perbuatan teror digunakan apabila tidak ada jalan lain yang dapat ditempuh untuk melaksanakan kehendaknya.

Kata "terror" menurut arti bahasa arab disebut dengan istilah "irhab". Kamus Al-Munawwir mendefinisikan Rahiba-Ruhbatan, wa ruhbanan, wa rohab ban, ruhbanan sebagai khaafa "takut". Sedangkan kata Al-irhab diterjemahkan dengan intimidasi.(Adian Husaini, 2001:83)Terorisme digunakan sebagai senjata psikologis untuk menciptakan suasana panik, tidak menentu serta menciptakan ketidak percayaan masyarakat terhadap kemampuan pemerintah dan memaksa masyarakat atau kelompok tertentu untuk mentaati kehendak pelaku teror. Terorisme tidak ditujukan langsung kepada lawan, akan tetapi perbuatan teror justru dilakukan dimana saja dan terhadap siapa saja. Dan yang lebih utama, maksud yang ingin disampaikan oleh pelaku teror adalah agar perbuatan teror tersebut mendapat perhatian yang khusus atau dapat dikatakan lebih sebagai psy-war.

Manullang memberikan pengertian terorisme sebagai suatu cara untuk merebut kekuasaan dari kelompok lain(A.C. Manullang, 2001: 151)

Kelompok Negara-negara Eropa Timur beserta beberapa negaranegara berkembang lainnya memberi batasan teror dalam dua kategori, yaitu terror individual (organisasi terror yang dijadikan bisnis/bayaran untuk mencapai target sponsor) dan terror Negara (Negara kolonialis terhadap Negara-negara jajahan atau sebaliknya). (A.C. Manullang, 2001: 153)

Dari berbagai batasan pengertian terorisme di atas, jelas belum adanya keseragaman definisi terorisme. Namun demikian terorisme mempunyai ciri dasar sebagai berikut: penggunaan atau ancaman kekerasan, adanya unsur penda- dakan/kejutan, direncanakan dan dipersiapkan secara cermat dan matang, menimbulkan ketakutan yang 
meluas atau membuat kehancuran material atau perekonomian, mempunyai tujuan politik yang jauh lebih luas dari sasaran/korban langsungnya.

Undang-undang Terorisme, dalam ketentuam umumnya memberikan definisi yuridis tentang terorisme yaitu tindak Pidana Terorisme adalah segala perbuatan yang memenuhi unsur-unsur tindak pidana sesuai dengan ketentuan Undang-undang. Dengan demikian Undang-undang tersebut menunjuk bahwa Tindak Pidana Terorisme adalah keseluruhan tindak pidana.Ciri-ciri terorisme adalah sebagai berikut:

1) Organsisasi yang baik, berdisiplin tinggi, militan. Organsisasinya merupakan kelompok-kelompok kecil, disiplin dan militansi ditanamkan melalui indoktrinasi dan latihan yang bertahun - tahun.

2) Mempunyai tujuan politik, tetapi melakukan perbuatan kriminal untuk mencapai tujuan.

3) Tidak mengindahkan norma-norma yang berlaku, seperti agama, hukum,dan lain-lain.

4) Memilih sasaran yang menimbulkan efek psikologis yang tinggi untuk menimbulkan rasa takut dan mendapatkan publikasi yang luas.(Abdul Wahid, dkk, 2004:29)

Karakteristik TerorismeDapat ditinjau dari 4 macam pengelompokan, yaitu :

1) Karakteristik organisasi yang meliputi: organisasi, rekrutmen, pendanaan dan hubungan intemasional. Karakteristik operasi yang meliputi : perencanaan, waktu, taktik dan kolusi.

2) Karakteristik perilaku yang meliputi : motivasi, dedikasi , disiplin , keinginan membunuh dan keinginan menyerah hidup-hidup.

3) Karakteristik sumber daya yang meliputi : latihan/kemampuan, pengalaman perorangan di bidang teknologi, persenjataan, perlengkapan dan transportasi. (Abdul Wahid, dkk, 2004:30) 
a. Perkembangan terorisme

Perkembangan terorisme meningkat secara signifikan sejak diawal tahun 1970-an. Dalam periode itu, terorisme berkembang mengusung agama tertentu, perjuangan kemerdekaan, pemberontakan, gerilya, bahkan teror dilakukan demi menegakkan dan melanggengkan kekuasaannya. Ketidakstabilan dunia dan munculnya frustrasi sekelompok masyarakat di berbagai negara menuntut hak-hak yang dianggap fundamental dan sah, sehingga memicu meluasnya terorisme. Kegiatan terorisme dalam berbagai bentuk, terus berkembang dan semakin meluas keberbagai negara seperti yang terjadi pada serangan bom di World Trade Centre (WTC) di Amerika Serikat pada 11 September 2001, yang berlanjut pada terjadinya serangkaian aksi teror seperti yang terjadi di Indonesia yakni Bom Bali I (2002), Bom Bali II (2005), peledakan Hotel Marriot Jakarta dan di depan Kedubes Australia, Kuningan Jakarta hingga peledakan bom seperti di Rusia, Mesir, Spanyol, Inggris, bahkan bom bunuh diri Irak pasca pendudukan negara koalisi global.A.C. (Manulang DR, 2006:17)

Terorisme harus diakui sebagai suatu permasalahan global dan menjadi bentuk baru perang dan merupakan ancaman yang sewaktu-waktu terjadi dan menjadi ancaman nyata bagi dunia. Apabila dilihat dari trend perkembangan saat ini dan yang akan datang menunjukkan bahwa kegiatan terorisme semakin meningkat baik dalam kualitas maupun kuantitas yang dapat berpotensi mengganggu stabilitas keamanan ditingkat internasional, regional maupun nasional. Sebagai salah satu ancaman yang dapat membahayakan situasi keamanan suatu negara, terorisme saat ini sudah menjadi ancaman global dengan jaringan yang bersifat internasional.Keberadaan terorisme sendiri di Indonesia tidak dapat dipungkiri ketika bom berkekuatan besar meluluh lantakan Bali pada tanggal 12 Oktober 2002, sebuah tempat pariwisata internasional yang selama ini menjadi kebanggaan kita bersama.Meskipun beberapa peristiwa teror pernah melanda Indonesia sebelumnya, namun bom Bali merupakan peristiwa "spektakuler" yang berhasil dilakukan oleh kelompok 
teroris.Penilaian ini muncul selain dari jumlah korban yang ditimbulkan juga karena sebagian besar korbannya adalah warga negara asing (WNA) yang sedang berlibur di Bali.

Berbagai bentuk ancaman yang dilakukan oleh teroris kepada pemerintah atau pihak yang berseberangan dengan kepentingan mereka dengan melakukan berbagai cara diantaranya pembunuhan, penganiayaan, penculikan, perampokan, intimidasi dan pembajakan. Seiring dengan perkembangan situasi internasional, maka di Indonesia sendiri menggunakan pola teror oleh kelompok yang berseberangandengan pemerintah kerap dilakukan didalam mencapai tujuan mereka menggunakan pola atau bentuk teror yang terus berkembang dengan cukup pesat. Beberapa kejadian di dalam negeri seperti konflik horizontal di Poso, Ambon, usaha-usaha disintegrasi oleh Organisasi Papua Merdeka (OPM) di Papua dan beberapa gerakan separatis lainnya telah menggunakan pola-pola kegiatan terorisme dalam melakukan aksiaksinya.

\section{Landasan Pemikiran}

a. Landasan Idiil.

Pancasila merupakan dasar, falsafah dan ideologi negara, yang berisi nilai-nilai moral dan etika dalam kehidupan bermasyarakat, berbangsa dan bernegara. Sebagai nilai moral dan etika kebangsaan, pengamalan Pancasila harus diwujudkan dalam pola pikir, pola sikap dan pola tindak bagi setiap warga negara Indonesia di dalam mengabdikan dirinya guna menyelenggarakan pertahanan negara sesuai dengan kedudukan dan fungsinya masing-masing. Nilai-nilai tersebutmeliputi keselarasan, keserasian, keseimbangan, persatuan dan kesatuan, kerakyatan, kekeluargaan, dan kebersamaan.Nilai-nilai Pancasila telah teruji dan diyakini kebenarannya sebagai pemersatu bangsa dalam membangun dan menata kehidupan berbangsa serta bernegara yang lebih baik dan berdaya saing, oleh karena itu Pancasila harus melandasi TNI/TNI AD dalam 
memerangi terorisme berskala nasional maupun internasional demi tegaknya NKRI.

b. Landasan Konstitusi.

Undang-Undang Dasar Negara Republik Indonesia 1945 (DUD 1945) adalah sumber dari segala sumber hukum. UUD 1945 memberikan landasan serta arah dalam pengembangan sistem serta penyelenggaraan pertahanan negara. Substansi pertahanan negara yang terangkum dalam Pembukaan dan Pasal-pasal UUD 1945 di antaranya adalah pandangan bangsa Indonesia dalam melihat diri dan lingkungannya, tujuan negara, sistem pertahanan negara, serta keterlibatan warga negara. Selanjutnya didalam pasal 30 UUD 1945 disebutkan bahwa tiap warga negara berhak dan wajib dalam usaha pembelaan negara yang syarat-syaratnya diatur dari UU diatas, oleh karena itu diperlukan organisasi TNI/TNI AD (satuan anti teror dan satuan intelijen) yang kuat dan profesional untuk mengatasi terorisme.

c. Landasan hukum.

1) Undang-Undang Republik Indonesia Nomor 15 Tahun 2003 Tentang Penetapan Peraturan Pemerintah (PP) Pengganti Undang-Undang Nomor 1 Tahun 2002 Tentang Pemberantasan Tindak Pidana Terorisme. Dalam UU RI No. 15 Tahun 2003 tentang Pemberantasan Tindak Pidana Terorisme (Anti Terorisme) Pasal 43 disebutkan bahwa "Dalam rangka pencegahan dan pemberantasan tindak pidana terorisme, Pemerintah Republik Indonesia melaksanakan kerja sama internasional dengan negara lain di bidang intelijen, kepolisian dan kerjasama teknis lainnya yang berkaitan dengan tindakan melawan terorisme sesuai dengan ketentuan peraturan perundang-undangan yang berlaku.(Pemerintah RI, UU RI No : 15 thn 2003,2003:20). Pasal ini mengisyaratkan pentingnya bagi Indonesia untuk melakukan kerjasama dengan negara ASEAN dalam pencegahan aksi terorisme. Undang-Undang Republik Indonesia Nomor 15 Tahun 2003 Tentang Penetapan Peraturan Pemerintah (PP) Pengganti Undang-Undang 
Nomor 1 Tahun 2002 Tentang Pemberantasan Tindak Pidana Terorisme, menjadi Undang-Undang. Pada pasal 26 ayat 1 disebutkan bahwa untuk memperoleh bukti permulaan, penyidik dapat menggunakan setiap laporan intelijen yang telah ditetapkan oleh Ketua Pengadilan Negeri. Selanjutnya di pasal 27 dijelaskan tentang alat bukti yang dapat digunakan antara lain informasi maupun data dan rekaman yang dapat dilihat, dibaca atau didengar. Kedua hal ini dapat dijadikan dasar pemikiran dalam setiap pelaksanaan tugas intelijen yang berkaitan dengan pemberantasan tindak pidana terorisme, karena dalam PP ini telah dijelaskan tentang kemungkinan pelibatan intelijen dan macam bukti-bukti yang diperlukan.

2) UU RI No. 3 tahun 2002 tentang Hanneg. Dalam pasal 7 ayat (2) tentang Penyelenggaraan Pertahanan Negara disebutkan Sishanneg dalam menghadapi ancaman militer menempatkan TNI sebagai komponen utama dengan didukung oleh komponen cadangan dan komponen pendukung. (Dephan.2005:37) Selanjutnya pada penjelasan ayat tersebut yang termasuk ancaman militer adalah ancaman yang menggunakan kekuatan bersenjata terorganisir yang dinilai mempunyai kemampuan yang membahayakan kedaulatan negara, keutuhan wilayah negara dan keselamatan segenap bangsa. Dalam wujudnya ancaman militer dapat berupa aksi teror bersenjata yang dilakukan oleh jaringan terorisme internasional yang bekerjasama dengan kelompok radikal dalam negeri. Untuk mampu melaksanakan tugas tersebut secara optimal antara lain diperlukan kemampuan intelijen yang handal khususnya dalam menghadapi terorisme.

3) UU RI TNI No 34 tahun 2004 tentang TNI. Pada pasal 7 ayat $2 b$ point ke 3 disebutkan bahwa tugas pokok TNI melalui operasi militer selain perang (OMSP) adalah mengatasi aksi terorisme. Dalam mengatasi aksi terorisme TNI tidak melakukan tugas/ bantuan kepada instansi manapun. Pelaksanaan tugas yang diamanatkan pada point ini berbeda dengan yang tertera di point 9 s.d 14, dimana TNI ditugaskan untuk 
memberikan bantuan pada instansi-instansi yang disebutkan. Berdasarkan Undang-Undangtersebut jelaslah bahwa TNI dapat dan harus berperan aktif dalam mengatasi aksi-aksi terorisme. Sehingga secara undang-undang jika terjadi aksi terorisme di Indonesia, maka wajar bila TNI ikut dipersalahkan. Mantan Direktur Jenderal Strategi Pertahanan Dephan Mayjen (Purn) Sudrajat yang banyak terlibat dalam pembahasan UU TNI berpendapat, tindakan atas terorisme itu dapat dilakukan militer yang dikategorikan dalam operasi militer selain perang atau dikenal sebagai military operations other than war (MOOTW).(Kompas, 14 Oktober 2005)

4) Resolusi dewan keamanan PBB. (A.c. Manulary, DR, 2006:255)Resolusi Dewan Keamanan PBB (UNSC) No. 1373/2001. Resolusi PBB ini merupakan konvensi yang menegaskan bahwa terorisme merupakan kejahatan yang mengancam perdamaian dan keamanan umat manusia sehingga seluruh negara anggota Perserikatan Bangsa-Bangsa (PBB), termasuk Indonesia wajib mendukung dan melaksanakannya. Substansi Resolusi Dewan Keamanan PBB tersebut menyebutkan bahwa tindakan melawan terorisme di antaranya dapat dilakukan dengan mencegah pendanaan terhadap terorisme, pembekuan keuangan para teroris, melarang warga negara untuk mendanai teroris, mengeliminir suplai senjata, serta menerapkan upaya preventif termasuk peringatan dini ke negara lain melalui pertukaran informasi.

5) KTT terakhir ASEAN di Bali tahun 2003 adalah tonggak dari perkembangan ASEAN dalam era globalisasi.(Bantarto Bandoro,2003) Dalam KTT itu ditegaskan kembali bahwa mekanisme multilateral merupakan pilihan kebijakan yang tepat untuk menyelesaian masalahmasalah regional. Lompatan besar ASEAN adalah dengan telah diterimanya sebuah usul untuk membangun sebuah komunitas ASEAN (F. Andrea dalam edisi ini.) tercantum dalam Bali Concord II,.(Bantarto Bandoro,2003)yang ditopang oleh tiga pilar, yaitu 
komunitas ekonomi (ASEAN Economic Community), komunitas sosial dan budaya (ASEAN Social and Cultural Community) dan komunitas keamanan (ASEAN Security Community). ASEAN Security Community adalah sebuah komunitas yang dibentuk oleh negaranegara ASEAN pada tanggal 7 Oktober 2003 di Bali, (Indonesia), ketika digelarnya KTT ASEAN yang kemudian menyepakati sebuah deklarasi yang kemudian dikenal dengan Bali Concord II.

6) Deklarasi ASEAN dalam memerangi terorisme.(Bantarto Bandoro,2003). Deklarasi KTT ASEAN dalam memerangi terorisme pasca serangan Teror Bom di Bali. Terorisme telah menjadi ancaman paling menakutkan bagi negara-negara didunia dewasa ini dan bisa mengancam wilayah manapun,termasuk ASEAN. Agar dapat mengantisipasi kemungkinan serangan lanjutan pasca tragedi Bom Bali, tanggal 5-6 November 2002 di Brunei Darussalam negara-nagara ASEAN telah menandatangani sebuah deklarasi. Pada intinya mengecam segala bentuk tindakan terorisme oleh karenanya perlu diadakan kerjasama militer negara-negara ASEAN untuk mencegah masuknya teroris kewilayah ASEAN umumnya dan Asia Tenggara khususnya.

d. Landasan Operasional.

1) Doktrin Tridarma Eka Karma (Tridek) TNI. Sebagai sebuah organisasi TNI mempunyai pedoman dalam pelaksanaan tugas pokok dan perannya sebagai alat pertahanan negara berupa Doktrin TNI. Dalam doktrin tersebut pada pasal pembinaan kemampuan disebutkan bahwa kemampuan intelijen strategis, taktis dan teknis disiapkan untuk senantiasa melaksanakan penyelidikan, pengamanan dan penggalangan dalam rangka mendukung pembinaan dan penggunaan kekuatan TNI. Hal inilah yang melandasi pola pikir, pola sikap dan pola tindak dalam pembinaan kemampuan dan penggunaan satuan anti teror TNI guna mendukung tercapainya tugas pokok TNI. 
2) UU N0 39 tahun 1999 tentang HAM. Pada pasal 2 disebutkan bahwa Negara Republik Indonesia mengakui dan menjunjung tinggi hak asasi manusia dan kebebasan dasar manusia sebagai hak yang secara kodrati melekat pada manusia yang harus dilindungi, dihormati, dan ditegakkan demi peningkatan martabat kemanusiaan, kesejahteraan, kebahagiaan dan kecerdasan serta keadilan. Pada pasal inimengandung pengertian bahwa setiap aparat intelijen TNI AD dalam melaksanakan tugasnya secara preventif yaitu untuk melindungi masyarakat dari aksi terorisme disamping itu harus tetap menghormati dan menegakkan HAM sebagai hukum positif yang berlaku.

\section{Analisa Aspek Legislasi.}

Dalam penanggulangan terorisme, Indonesia telah memiliki undang-undang khusus tentang pemberantasan terorisme dan sudah sudah dilaksanakan oleh institusi TNI maupun Polri namun masih banyak permasalahan hukum yang belum dapat diakomodasi oleh undang-undang tersebut serta kesulitan mengimplementasikannya di lapangan.Salah satu yang menonjol adalah ketidakmampuan penindakanterhadap jaringan yang tidak melakukan tindakan kekerasan, namun aktif dalam menyebarkan paham radikalnya yang menantang ideologi Pancasila dan bentuk NKRI, untuk itu perlu dianalisa dan dicari jalan solusinya agar kedua institusi tersebut dapat sejalan dalam mengatasi aksi-aksi terorisme.

Analisa aspek legitimasi dimulai dari dasar hukum TNI melaksanakan operasi mengatasi terorisme. Sesuai dengan UndangUndang RI Nomor 34 tahun 2004 tentang Tentara Nasional Indonesia, TNI mempunyai tugas yang telah diatur lebih lanjut dalam pasal 7 yang menyatakan bahwa tugas pokok TNI adalah menegakkan kedaulatan negara, mempertahankan keutuhan wilayah Negara Kesatuan Republik Indonesia yang berdasarkan Pancasila dan Undang-Undang Dasar Tahun 1945, serta melindungi segenap bangsa dan seluruh tumpah darah Indonesia dari ancaman dan gangguan terhadap keutuhan bangsa dan 
negara. Tugas sebagaimana dimaksud diatas dilakukan dengan pola OMP dan pola OMSP. Tugas tugas OMSP sebagai berikut :

a. Mengatasi gerakan separatis bersenjata.

b. Mengatasi aksi pemberontakan bersenjata.

c. Mengatasi aksi terorisme.

d. Mengamankan wilayah perbatasan.

e. Mengamankan objek vital nasional yang bersifat strategis.

f. Melaksanakan tugas perdamaian dunia sesuai dengan kebijakan politik luar negeri.

g. Mengamankan Presiden dan Wakil Presiden beserta keluarganya

h. Memberdayakan wilayah pertahanan dan kekuatan pendukungnya secara dini sesuai dengan sistem pertahanan semesta.

i. Membantu tugas pemerintahan di daerah.

j. Membantu Kepolisian Negara Republik Indonesia dalam rangka tugas keamanan dan ketertiban masyarakat yang diatur dalam undangundang.

k. Membantu mengamankan tamu negara setingkat kepala negara dan perwakilan pemerintah asing yang sedang berada di Indonesia.

1. Membantu menanggulangi akibat bencana alam. Pengungsian, dan memberikan bantuan kemanusiaan.

m. Membantu pencarian dan pertolongan dalam kecelakaan (search and rescue).

n. Membantu pemerintah dalam mengamankan pelayaran dan penerbangan terhadap pembajakan, perompakan dan penyelundupan. ( Dephan. 2005: 74)

Di dalam melaksanakan tugas tersebut diatas maka TNI melaksanakan perannya sebagai alat negara di bidang pertahanan, dalam menjalankan tugasnya berdasarkan kebijakan dan keputusan politik negara yaitu kebijakan dan keputusan politik yang dilakukan oleh Pemerintah bersama Dewan Perwakilan Rakyat (DPR) dan dirumuskan melalui mekanisme hubungan kerja antara Pemerintah dan DPR, seperti rapat 
konsultasi dan rapat kerja yang sesuai dengan peraturan perundangundangan. Didalam undang-undang tersebut juga dikatakan bahwa dalam melaksanakan peran dan tugasnya, TNI berfungsi sebagai :

a. Penangkal terhadap setiap bentuk ancaman militer dan ancaman bersenjata dari luar dan dalam negeri terhadap kedaulatan, keutuhan wilayah, dan keselamatan bangsa.

b. Penindak terhadap setiap bentuk ancaman sebagaimana dimaksud pada point diatas.

c. Pemulihan terhadap kondisi keamanan Negara yang terganggu akibat kekacauan keamanan. ( Dephan. 2005: 73)

Sesuai dengan UU Hanneg dan UU TNI, didalam melaksanakan fungsinya, TNI mempunyai kemampuan dibidang intelijen, teritorial, tempur dan keamanan. Kemampuan tersebut perlu dimanfaatkan dan dapat menjadi unsur penting dalam strategi nasional penanggulangan terorisme. Jaringan intelijen TNI dapat mendukung memberikan informasi penting dan mendeteksi tentang jaringan dan aktivitas terorisme di Indonesia kepada satuan anti terorisme TNI maupun aparat penegak hukum khususnya Polri namun sampai saat ini belum terlaksana secara optimal termasuk dalam mengimplementasikan tugas pokok, peran dan fungsi TNI dalam mengatasi terorisme dilapangan. Dari analisa diatas didapat beberapa temuan yang merupakan hambatan dalam operasional TNI antara lain :

a. Untuk OMSP nomor 1 s.d. 7 merupakan peran utama TNI sehingga bisa masuk dalam rencana operasi TNI karena langsung mengancam kedaulatan, keutuhan wilayah, keselamatan bangsa dan tumpah darah Indonesia. Dengan demikian mengatasi terorisme merupakan tugas utama TNI.

b. Sampai saat ini belum ada kebijakan operasional yang mengatur perbantuan dari instansi lain kepada TNI sedangkan kebijakan itu sangat diperlukan karena mengatasi terorisme tidak bisa diatasi sendiri karena :

1) TNI mempunyai kemampuan dan batas kemampuan.

2) Polri mempunyai kemampuan dan batas kemampuan. 
3) Sistem pertahanan negara RI menganut sistem pertahanan semesta.

4) Dalam mengatasi terorisme tidak bisa dilakukan hanya oleh satu institusi saja (TNI).

c. Permasalahan lain muncul ketika TNI mengacu Undang-Undang RI No 34 Tahun 2004 (tentang TNI dalam pasal 7 ayat (2) huruf b angka 3 dalam mengatasi terorisme), sedangkan Polri mengacu Undang-Undang RI No 2 tahun 2002 tentang Polri pasal 41 mengenai mekanisme perbantuan TNI kepada Polri, dimana mereka mengartikan tugas TNI hanya membantu Polri dalam mengatasi terorisme. Kedua UU tersebut memiliki amanat aturan pelaksanaan yang berbeda. Undang-Undang TNI mengamanatkan aturan pelaksanaannya dalam undang-undang, sedangkan Undang-Undang Polri mengamanatkan perbantuan TNI dalam penanganan terorisme diatur dalam Peraturan Pemerintah, dengan demikian dapat di artikan bahwa masih adanya perbedaan persepsi dalam mengatasi terorisme antara kedua instansi tersebut.

d. Dalam penjelasan Undang-Undang Rl No 2 Tahun 2002 tentang Kepolisian Rl pasal 15 ayat (2) huruf h bahwa kewenangan Polisi mengatasi kejahatan internasional dan salah satu diantaranya terorisme. Polri dalam penanganan terorisme di Indonesia menggunakan pendekatan hukum padahal kondisi nyata di lapangan pendekatan hukum saja tidak cukup tetapi diperlukan juga pendekatan keamanan.

e. Terdapat beda penafsiran antara keamanan negara (nasional) yang menjadi tugas seluruh komponen bangsa termasuk TNI dengan keamanan ketertiban masyarakat yang menjadi tugas Polri yang diartikan sebagai keamanan secara keseluruhan, sehingga seluruh keamanan menjadi tugas Polri, pertahanan menjadi tugas TNI.

f. Khusus untuk tugas TNI dalam OMSP nomor 10, membantu Polri dalam rangka tugas Kamtibmas yang diatur oleh undang-undang. Pada kenyataannya hal tersebut belum dijelaskan secara rinci bentuk bantuan apakah berupa kekuatan atau kemampuan, atau kekuatan dan 
kemampuan, sehingga muncul wacana apabila TNI tidak memberi bantuan akan di PTUN-kan.

g. Dalam tugas perbantuan ini sering kali sesuai eskalasi ancaman kekuatan TNI yang dikerahkan bisa melebihi kekuatan Polri yang dibantu dan keamanan sudah beralih dari keamanan dan ketertiban masyarakat menjadi keamanan wilayah/negara. Faktor kritis disini adalah siapa yang memutuskan/ menentukan alih kodal.

Setelah ditentukannya wewenang TNI dan Polri seperti tersebut diatas, maka selanjutnya perlu diselesaikan masalah dibawah ini agar permasalahan aspek legislasi dapat terselesaikan. Sesuai dengan sifatnya bahwa Terorisme itu sendiri merupakan sesuatu yang tidak mudah ditentukan identitasnya, sulit untuk mengandalkan hanya pada upaya penegakan hukum karena terorisme memang bukan merupakan kejahatan biasa (extraordinary crime). Penanggulangan kasus terorisme tidak dapat dihadapi semata dengan penegakan hukum yang bersifat represif. Perlu dilaksanakan upaya-upaya lain yang lebih komprehensif sesuai dengan sifat dan karakteristik khas kasus terorisme itu sendiri, yaitu upaya preemtif, preventif dan rehabilitatif dimana penanganannya juga perlu dilakukan secara integratif melibatkan berbagai elemen. Agar penanganan ancaman terorisme di Indonesia dapat terlaksana secara komprehensif maka permasalahan aspek legislasi harus diselesaikan dengan segera karena perkembangan terorisme semakin pesat dan akan menjadi ancaman di Abad ke 21. Adapun penyelesaiannya adalah:

a. Perlu kejelasan politik negara dalam hal aktualisasi siapa yang mengatasi terorisme.

b. Perlu dibentuk badan pelaksana operasi mengatasi terorisme.

c. Perlunya undang-undang yang mengatur siapa yang berperan sebagai peran utama dan peran pembantu dalam mengatasi terorisme.

d. Perlunya merumuskan Kebijakan Operasional dalam rangka pembentukan Komando Gabungan Terpadu Penanggulangan Terorisme atau badan dari institusi lintas sektoral yang dapat 
melakukan sinkronisasi satuan-satuan operasional dan satuan taktis (pemukul). (Asop Panglima TNI. 2008:12-13)

\section{Simpulan}

Secara empiris,sebenarnya selama ini TNI sudah dilibatkan untuk membantu kepolisian di dalam menghadapi ancaman dalam negeri semisal dalam penanganan konflik Ambon dan Konflik Poso.Mekanisme pelibatan itu berpijak pada Protap (Prosedur tetap) yang dimiliki oleh polisi maupun oleh TNI itu sendiri.Masalahnya adalah Protap bukanlah bagian dari tata peraturan perundang-undangan sehingga status hukumnya lemah dan tidak memiliki kekuatan mengikat (legaly binding). Dalam praktiknya,kadang kala justru terjadi rivalitas dan kurangnya koordinasi akibat kelemahan pengaturan tentangtugas perbantuan itu.

Rencana pengaturan tugas perbantuan TNI kepolisi dalam kerangka operasi militer selain perang sudah sepantasnya memperhatikan beberapa prasayarat berikut ini yakni tugas perbantuan baru bisa dilakukan apabila:

1. Adanya ancaman nyata dan tingkat eskalasinya telah meningkat tajam

2. Adanya kondisi dimana aparat kepolisian sudah tidak bisa lagi menanggulanginya secara sendiri

3. Adanya permintaan aparat kepolisian ke otoritas sipil untuk meminta perbantuan dari TNI

4. Adanyapenilaian dari otoritas sipilatas permintaan itu

5. Adanya keputusan dari otoritas sipil untuk melibatkan TNI membantu kepolisian maupun dalam menghentikan tugas perbantuan itu sendiri;

6. Memperhatikan prinsip proporsionalitas dalam pengerahan kekuatanTNI

7. Pelibatan TNI merupakan alternatif terakhir;

8. Memperhatikan tatanilai HAM dalam tugas perbantuan

9. Adanya pengawasan dan evaluasi dari otoritas sipil dari pelaksanaan tugas perbantuan itu. 


\section{E. Saran}

Berdasarkan analisis tentang pemberantasan terorisme oleh TNI, maka penulis memberikan saran sebagai berikut:

1. Perlunya kerjasama antara Polri dan TNI dalam upaya pemberantasan Terorisme sebagai bentuk keamanan dan pertahanan negara, dengan dasar hukum atau payung hukum yang jelas berdasarkan politik hukum yang dibuat pemerintah.

2. Pemerintah membuat keputusan politik negara dalam mengatasi terorisme melalui undang-undang yang mengatur siapa yang berperan sebagai peran utama (leading sektor) dan siapa sebagai peran pembantu dalam mengatasi terorisme.

3. Perlu dibentuk Badan Pelaksana Operasi mengatasi terorisme dari institusi lintas sektoral yang dapat melakukan sinkronisasi satuan-satuan operasional dan satuan taktis (pemukul).

4. Segera disyahkannya UU Keamanan Nasional sebagai payung hukum.

\section{F.Daftar Pustaka}

\section{Buku:}

A.C. Manullang. 2001.Menguak Tabu Intelijen: Teror, Motif dan Rezim. Jakarta : Panta Rhei.

A.c. Manulary. DR.2006 Terorisme dan Perang Intelejen. Jakarta : Hanna Zaitun.

Abdul Wahid. Dkk. 2004, Kejahatan Terorisme Perspektif Agama, HAM,Bandung: Penerbit PT. Rafika Aditama

Bantarto Bandoro. 2003.Drawing a new blue print ASEAN, the Jakarta Post

Dephan.2005 Buku Himpunan Perundang-undangan yang terkait dengan penyelenggaraan dan pengolahan pertahanan. UU RI No 34 th 2004 tentang TNI, Jakarta.

Jimly Asshiddiqie.2003Struktur Ketatanegaraan Indonesia Setelah Perubahan Keempat UUD Tahun 1945. Makalah Disampaikan dalam Simposium yang dilakukan oleh Badan Pembinaan Hukum Nasional, Departemen Kehakiman dan HAM 
Jurnal:

Jatmikhoadhi.2017. "Penguatan Community Development (Comdev)Untuk Cegah Radikalisme Dan Terorisme".Jurnal Yudagama.Vol 37.no 1.Edisi Maret

\section{Undang-undang :}

UUD 1945

UU TNI NO 34 Tahun 2004

UU No. 15 Tahun 2003 Tentang Tindak Pidana Terorisme

UU No. 2 Tahun 2002 Tentang Kepolisian Negara Kesatuan Republik Indonesia

Internet:

http://www.scribd.com/doc/4683235/terorisme-, diakses pada 5 Maret 2017, pukul $\underline{11.00 W I B .}$ 